\title{
New data on internal morphology of exceptionally preserved Nannirhynchia pygmaea (Morris, 1847) from the Lusitanian Basin (Brachiopoda, Early Jurassic, Portugal)
}

\author{
Mena Schemm-Gregory* and Maria Helena Henriques \\ Centro de Geociências da Universidade de Coimbra, Largo Marquês de Pombal, 3000-272 Coimbra, Portugal. \\ E-mail: Mena.Schemm-Gregory@dct.uc.pt, hhenriq@dct.uc.pt
}

\begin{abstract}
Received 28 September 2011

Accepted 23 February 2012

Published 3 August 2012

\section{Key Words}

Rhynchonellida

Brachiopoda

oceanic anoxic event

$3 \mathrm{D}$ reconstructions

Pyritized internal moulds of articulated shells of the Early Jurassic brachiopod taxon Nannirhynchia pygmaea were found in beds closely below the early Toarcian oceanic anoxic event in the Polymorphum Zone in Portugal. The material allows a detailed study of the outline of the muscle fields, the length and direction of the crura, and the orientation of the cardinalia, which are hitherto undescribed. Three-dimensional reconstructions of articulated shells of N. pygmaea occurring in a single horizon were produced to show the orientation and length of arcuiform crura. The preservation of internal moulds together with the three-dimensional reconstruction of the internal shell morphology allow a more precise description of the internal morphology of this taxon than it is possible with articulated shells and serial sections.
\end{abstract}

Early Toarcian

\section{Introduction}

Species of Nannirhynchia Buckman, 1918 are particularly abundant in the stratigraphic record of Early Jurassic age outcropping in the Lusitanian Basin, where they represent important biostratigraphic tools, especially where ammonites are missing or are not well preserved. An attempt of a correlation scheme of ammonite and brachiopod zones from the Mediterranean and the northern European provinces is introduced in Alméras et al. (1997); however, not all boundaries are well-defined. Three taxa of Nannirhynchia occur in the stratigraphic record of different palaeoenvironments in Portugal:

(1) external platform: N. pygmaea (Morris, 1847), Polymorphum Zone (Davidson \& Morris 1847),

(2) subsiding areas: N. cotteri Choffat, 1995, Speciosum Zone (Alméras et al. 1995), and

(3) marl deposits in low energy environments: $N$. delgadoi Choffat, 1995, Speciosum Zone (Alméras et al. 1995).
The genus Nannirhynchia was first described at the beginning of the 20th century with material from the Tenuicostatum Zone from Ilminster (Somersetshire/England); extensive Nannirhynchia collections in Portugal were carried out by Paul Choffat (1849-1919) and are stored at the Geological Museum in Lisbon. Alméras et al. (1995) revised the genus with special attention on Portuguese material and established the first Nannirhynchia-based biostratigraphy for the Lusitanian Basin. Even though they pointed out that a high percentage of $N$. pygmaea in the S. Gião Formation (Barbosa et al. 1988) is preserved as pyritized internal moulds, no description of muscle scars is given. Up to now, the internal morphology of N. pygmaea is only known from two-dimensional serial sections. Savage et al. (2002) pointed out the taxonomic importance of rhynchonellid muscle scars in comparison to other internal features, but stressed that they are commonly poorly known because of the limitations of clarity of the serial section. Furthermore, the problems of interpretation, reconstruction, and comparison of the internal shell morphology of different kinds of fossil preservation, e.g., silicified

\footnotetext{
* Corresponding author
} 


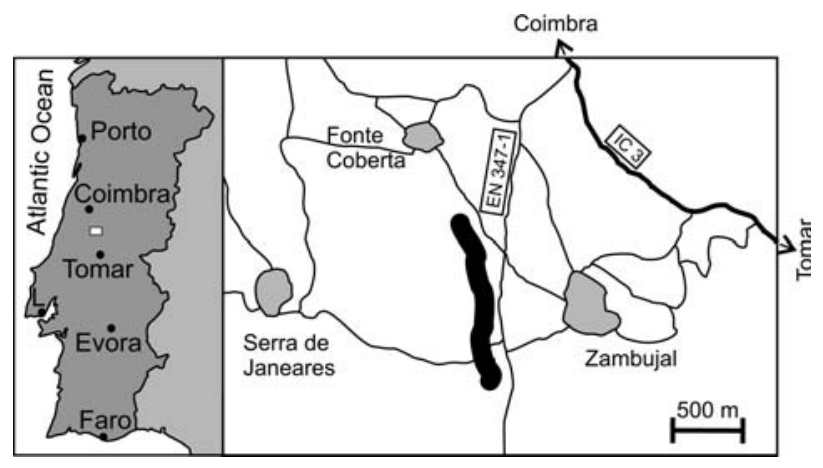

Figure 1. Geographic map showing the locality with Nannirhynchia pygmaea (Morris, 1847). L. = Lisbon.

shells and internal moulds, are complicating the taxonomic study. Even though the complete pyritization of the internal moulds allows a detailed study of the size and outline of the muscle fields and latex casts show the structure and orientation of the cardinalia, the length and form of crura is impossible to study in this kind of preservation. Therefore, serial sections of articulated shells are essential to examine these fragile and faint shell structures. We use modern computer supported reconstruction techniques to prepare three-dimensional images of the internal shell morphology and crura based on two-dimensional photos of grinding surfaces. (The use of CT scans is impossible with our material because the contrast between sediment and shell is not strong enough to provide useful images.) Two-dimensional drawings of selected serial sections are given in Alméras et al. (1995, figs 5, 6). Here we present a detailed description of ventral and dorsal muscle scars and the internal shell morphology according to threedimensional reconstructions after digitized serial sections and latex casts of internal moulds of Nannirhynchia pygmaea to allow future comparative studies of different kinds of preservation of this fossil group.

\section{Material and methods}

Institutional abbreviations. UC, Universidade de Coimbra, Coimbra, Portugal.

Other abbreviations. inv. no., inventory number; L, length; MP, Section Maria Pares; T, thickness, TM, Topographic Mapsheet; W, width.

\section{Geological Settings}

Our material was collected from the Maria Pares [= Rabaçal (Alméras et al. 1995) = Zambujal (Gahr 2002)] section along both sides of the road Zambujal - Serra de Janeares, approximately $15 \mathrm{~km}$ south of Coimbra (Central Portugal), TM 251 Condeixa-a-Nova $(1: 25,000)$ of the Serviços Cartográficos do Exército. The section is a reference section for Toarcian and Aalenian record in the Northern Lusitanian Basin and describes a N-S striking belt of about $1 \mathrm{~km}$ length consisting of alternating marly and calcareous beds (Fig. 1). A detailed sedimentological description of this section is given in Duarte (1990), a biostratigraphic description is provided by Mouterde et al. (1965). Nannirhynchia pygmaea occurs in the Polymorphum Zone $[=$ Tenuicostatum Zone] of the S. Gião Formation [= Margas calcárias de S. Gião (Barbosa et al. 1988)]. Duarte \& Soares (2002) subdivided this formation into five members, of which according to Soares et al. (2007), the member "marly limestones with Leptaena fauna" [= Bed 40c (Mouterde et al. 1964-65) = MST1 (Duarte 1995, 1997)], yielded N. pygmaea (Fig. 2). It has to be stressed that according to Alméras et al. (1995) and Vörös (2002), the Leptaena fauna sensu Deslongchamps (1853) should be called Koninckella and Nannirhynchia fauna because Leptaena Dalman, 1828 describes a Palaeozoic strophomenid brachiopod genus and is, therefore, an inaccurate term for beds of Early Jurassic age. The environmental settings of N. pygmaea in the Lusitanian Basin is interpreted as a carbonate ramp dipping toward the NW. Further details are given in Duarte et al. (2004).

Strata of the Polymorphum Zone in the Lusitanian Basin are characterized by a high pyrite content. All of the numerous internal moulds of juvenile Catacoeloceras sp. and juvenile harpoceratid ammonites, gastropods, and crinoid stems, almost $20 \%$ of Nannirhynchia specimens but less percentage of Liospiriferina Rousselle, 1977 and Orthotoma Quenstedt, 1869 taxa are pyritized. Beds with the high pyrite content are marking the onset of the Toarcian anoxic event resulting in a mass extinction which, e.g., the spiriferid and athyrid brachiopods did not survive (Wignall et al. 2005). The appearance of the Karoo Ferrar flood basalt Province is regarded as the cause for the increase of warming volcanic $\mathrm{CO}_{2}$ resulting in an acidification of oceanic surface waters (Cohen et al. 2004; Mattioli et al. 2004), however, this theory is still a matter of debate (Jourdan et al. 2005). The pyrite content in this time interval occurs only in the Tethyan but not in the Boreal Realm, where the Early Toarcian mass extinction event is described by the onset of a phase of black shale deposition (Hallam 1986; Little \& Benton 1995; Wignall et al. 2005).

\section{Material}

The material consists of articulated and isolated shells and pyritized internal moulds. Serial sections of articulated shells were prepared using a Struers Discoplan-TS grinding machine with slice-spacing of $25 \mu \mathrm{m}$ starting from apex in an anterior direction perpendicular to commissural plane. Grinding surfaces were subsequently digitized

\begin{tabular}{|c|c|c|c|c|c|}
\hline \multicolumn{3}{|c|}{ Geochronology } & $\begin{array}{c}\text { Ammonite } \\
\text { biostratigraphy }\end{array}$ & $\begin{array}{l}\text { Lithostratigraphy } \\
\text { (Lusitanian Basin) }\end{array}$ & $\begin{array}{l}\text { Members of } \\
\text { S. Gião Fm. }\end{array}$ \\
\hline MJ & \multicolumn{2}{|c|}{ Aalenian } & Opalinum & \multirow{3}{*}{$\begin{array}{l}\text { Póvoa da } \\
\text { Lomba Fm. }\end{array}$} & \\
\hline \multirow{9}{*}{ 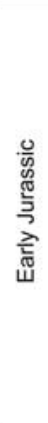 } & \multirow{8}{*}{ 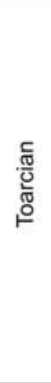 } & \multirow{4}{*}{ late } & Aalensis & & \\
\hline & & & Meneghinii & & \\
\hline & & & Speciosum & \multirow{6}{*}{ S. Giẫo Fm. } & Marl and marly limestone \\
\hline & & & Bonarelli & & Marl and marly limestone \\
\hline & & \multirow{2}{*}{ middle } & Gradata & & with sponge bioconstructions \\
\hline & & & Bifrons & & Marl and marly limestone \\
\hline & & \multirow{2}{*}{ early } & Levisoni & & Thin nodular limestone \\
\hline & & & Polymorphum & & $\begin{array}{l}\text { Marly limestone with } \\
\text { Leptaena fauna }\end{array}$ \\
\hline & \multicolumn{2}{|c|}{ Pliensbachian } & Spinatum & Lemede Fm. & \\
\hline
\end{tabular}

Figure 2. Stratigraphic subdivision of the early Toarcian in the central Lusitanian Basin. The oceanic anoxic event is indicated by the grey bar, the Nannirhynchia pygmaea yielding beds by the asterisk. Modified after Duarte \& Soares (2002), Duarte (2007) and Hesselbo et al. (2007). 
using a digital camera (Canon 300D). Three-dimensional reconstruction methods are those of Sutton et al. (2001, 2005), implemented using the custom SPIERS 2.05 software suite for registration, virtual preparation, and interactive visualization. The digital photos were subsequently manually aligned with SPIERSalign and in a second step, redrawn using different masks in SPIERSedit. The 3D images are copied out of SPIERSview. Latex casts of internal moulds were prepared to study the internal shell morphology and hinge structure. Drawings were done with the help of a camera lucida. Measurements are taken with a digital caliper rounded to the next $0.1 \mathrm{~mm}$. Specimens were coated with magnesium oxide prior to photographing with a digital camera.

The systematics follows the revised Treatise on Invertebrate Paleontology (Manceñido et al. 2002). The material is stored at the Laboratório de Geologia Sedimentar e Registo fóssil, Departamento de Ciências da Terra, Faculdade de Ciências e Tecnologia da Universidade de Coimbra (Portugal).

\section{Systematic palaeontology}

Order Rhynchonellida Kuhn, 1949

Superfamily Norelloidea Ager, 1959

Family Norellidae Ager, 1959

Subfamily Laevirhnchiinae Dagys, 1974

\section{Nannirhynchia Buckman, 1918}

Type species. Nannirhynchia subpygmaea Buckman, 1918, p. 67; by original designation.

Diagnosis. Minute, globose equibiconvex, polygonal, oval, or circular in outline; sulcate with well-marked median uniplication and fold rounded to flattopped; with few rounded costae anteriorly, otherwise smooth; umbo small, short, incurved; foramen small, circular to elongate, deltidial plates disjunct. Dental plates weak, subparallel to dorsally divergent, often almost fused to wall; dorsal median septum, septalium, and cardinal process absent; crura arcuiform. (After Manceñido et al. 2002, p. 1319.)

Stratigraphic and geographic occurrence. ?Pliensbachian, Toarcian to Bajocian; England, Portugal, France, Morocco, Algeria, Tunisia, ?Slovakia, ?Austria.

\section{Nannirhynchia pygmaea (Morris, 1847)}

Figures 3-5

1847 Terebratula pygmaea Morris in Davidson \& Morris, p. 256, pl. 19 , fig. 3 .

1995 Nannirhynchia pygmaea. - Alméras et al., p. 10-17, figs 2-6, pl. 1, figs 1-8. [see ibidem for further synonymy] 2002 Nannirhynchia pygmaea. - Gahr, p. 130, pl. 6, fig. 7.

Stratigraphic and geographic occurrence. Polymorphum Zone (early Toarcian); England, Portugal, France, Morocco, Algeria, Tunisia.

Type horizon and type locality. Leptaena beds, Toarcian; Ilminster (Somersetshire/England).

Material. 1232 specimens collected consist of 955 articulated shells (five of them were sectioned), 10 ventral shells, 11 dorsal shells, and 256 pyritized internal moulds of articulated shells. Measurements of representative specimens are listed in Tables 1,2 .

Emended diagnosis. Shells small, equibiconvex and with circular to hexagonal or elongate outline. Umbo straight to curved in the upper part. Ventral interarea with distinct deltidial lamellae. Costae coarse and rounded in cross-section. Sulcus and fold dominant, rounded in cross-section, and in a few cases with median costa or furrow. Muscle fields impressed and bordered by a muscle bounding ridge. Dorsal adductor field divided by two fine septa.

Description. Exterior - Shells small to very small (Tables 1,2 ) with circular to hexagonal or elongate outline and equibiconvex in longitudinal section. Shell surface smooth; the striae described by Buckman (1918) and Ager (1967) could not be observed on our material. Concentric growth lamellae rarely preserved (Figs 3AD). Anterior margin rounded and sulcate with a high sulcus tongue. Sulcus, fold, and costae coarse, rounded to rarely angular in cross section, and of same size. In a few cases sulcus and fold are showing a median costa or a median furrow (Figs 3C1, C2). On average two costae on each flank, but number may vary between one and four. Ventral umbo large, erect to suberect. Foramen small, circular to elongate elliptical, and meso- to hypothyrid (Fig. 3Q). Deltidial lamellae present but never fused in the posterior region.

Interior of ventral valve - Moderate accretion of secondary shell material in the apical region resulting in an impressed ventral muscle field (Figs 3N1, N2, 4D). Muscle scars short, less than $1 / 3$ of shell length, elongate, and elliptical in outline. Out of the umbo extends a myophragm preserved as a furrow on the internal mould, running in an anterior direction through the whole muscle field. In some specimens radial striae of the diductor scars are preserved at the anterior margin of the muscle field. Diductor and adductor scars are not well-differentiated. A strong muscle bounding ridge is present preserved as a profound furrow on the internal mould (Figs 3F1, M; 5A). Dental plates almost parallel to divergent in dorsal direction, short, thin, hardly thickened posterior, and leading into massive and rectangular teeth (Figs 3E, 4A3, C, D). Impressions of growth lamellae preserved at the anterior margin of the internal mould.

Interior of dorsal valve - Almost no development of secondary shell material in the apical region. Hinge plate coarse, parallel to commissural plane in juvenile forms, and curved ventrally in adults, divided, may be united posteriorly (Figs 4C, D). Cardinal process, septalium, and dorsal myophragm lacking (Figs 4A5, B1). Crural plates present, but may be partly embedded into secondary shell material in adult specimens, preserved as small lamellae leading into the arcuiform crura (Figs 4C, 5C). Crura short, extend to $1 / 4$ of shell length in an anterior direction, thin and parallel to each other in juvenile forms, but thickness increases in adult stages and orientation is becoming divergent in ventral direction to each other. Due to the accretion of secondary shell material, free portions of crura becoming shorter during ontogeny (Figs 4A6-7, B2-3). Inner socket ridges thick. Dental sockets round in cross section, large and thin (Figs 4C, D, 4C). Adductor field pyriform to teardrop-like in outline, large, up to $1 / 2$ of shell length, gently embedded into shell material, and bordered by a distinct muscle bounding ridge that is 

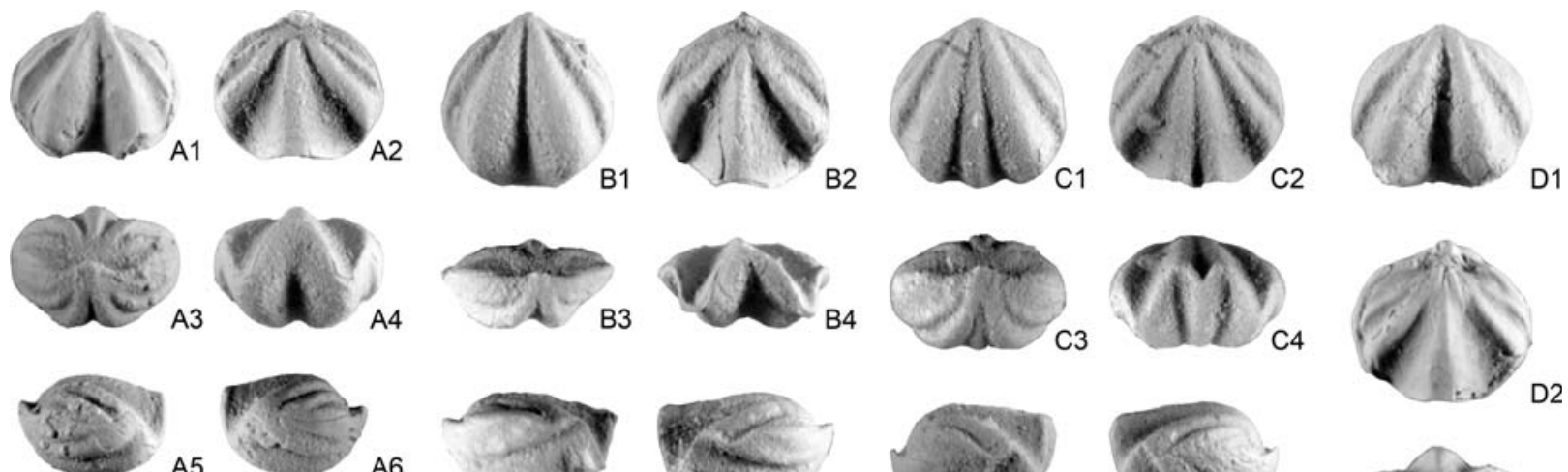

A5
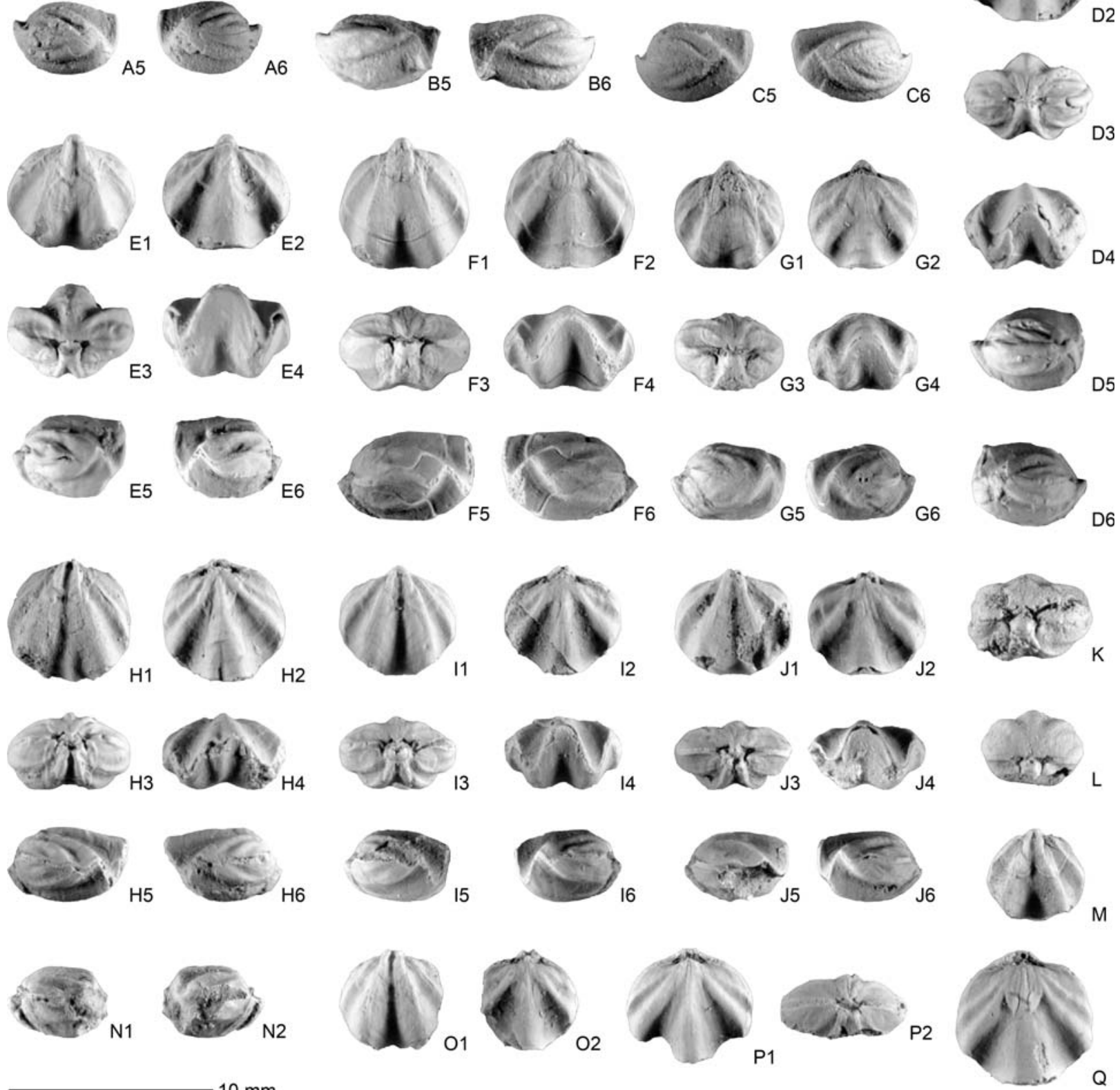

$10 \mathrm{~mm}$

thinner than the muscle bounding ridge in the ventral valve. Two radial, straight, and very fine septa are preserved, running through the entire muscle field in an anterior direction (Fig. 5B). Anterior margin of the adductor scars clearly lobate. Impressions of growth lamellae preserved on the anterior half of the internal mould.

Discussion. The complete pyritization of the internal moulds of articulated specimens and the three-dimen- sional reconstructions of serial sections of articulated shells provide exceptional data of the hitherto unknown internal morphology of Nannirhynchia pygmaea, such as the size of the muscle fields or the length and structure of the crura. Even though the outline of shell and number of costae are strongly variable (compare Alméras et al. 1995, fig. 4), the morphology of the muscle fields in both valves is relatively constant during ontogeny and among all morphotypes. Digitized three-dimensional reconstructions allow the study of the inter- 
Figure 3. Nannirhynchia pygmaea (Morris, 1847); section Maria Pares (Central Portugal); S. Gião Formation (Polymorphum Zone, early Toarcian); leg. M. Schemm-Gregory 2011. All figures magnified (3×). A. UC-MP-84-1. Ventral (1), dorsal (2), posterior (3), anterior (4), and lateral $(\mathbf{5}, \mathbf{6})$ views of articulated shell; B. UC-MP-67-3. Ventral (1), dorsal (2), posterior (3), anterior (4), and lateral $(\mathbf{5}, \mathbf{6})$ views of articulated shell; C. UC-MP-156-3. Ventral (1), dorsal (2), posterior (3), anterior (4), and lateral $(\mathbf{5}, \mathbf{6})$ views of articulated shell. Note median costa and median furrow; D. UC-MP-67-1. Ventral (1), dorsal (2), posterior (3), anterior (4), and lateral $(\mathbf{5}, \mathbf{6})$ views of articulated shell; E. UC-MP-86-3. Ventral (1), dorsal (2), posterior (3), anterior (4), and lateral $(\mathbf{5}, \mathbf{6})$ views of internal mould of articulated shell. Note embedded crural plates; F. UC-MP-156-8. Ventral (1), dorsal (2), posterior (3), anterior (4), and lateral $(\mathbf{5}, \mathbf{6})$ views of internal mould of articulated shell; G. UC-MP-156-17. Ventral (1), dorsal (2), posterior (3), anterior $(4)$, and lateral $(\mathbf{5}, \mathbf{6})$ views of internal mould of articulated shell. Note free parts of crural plates; H. UC-MP-156-2. Ventral (1), dorsal (2), posterior (3), anterior (4), and lateral $(\mathbf{5}, \mathbf{6})$ views of internal mould of articulated shell. Note median costa and median furrow; I. UC-MP-156-15. Ventral (1), dorsal (2), posterior (3), anterior (4), and lateral $(\mathbf{5}, \mathbf{6})$ views of internal mould of articulated shell; J. UC-MP-156-16. Ventral (1), dorsal (2), posterior (3), anterior (4), and lateral (5, 6) views of internal mould of articulated shell; K. UC-MP-66-1. Posterior view of internal mould of articulated shell; L. UC-MP64-5. Oblique posterior view of internal mould of articulated shell; M. UC-MP-156-9. Ventral view of internal mould of articulated shell; N. UC-MP-156-12. Lateral views of internal mould of articulated shell. Note embedded ventral muscle field; O. UC-MP-156-14. Ventral (1) and dorsal (2) views of internal mould of articulated shell; P. UC-MP-156-19. Dorsal (1) and posterior (2) views of dorsal internal mould; Q. UC-MP-65-2. Dorsal view of internal mould of articulated shell, shell material only preserved in ventral apical region. Note lateral septa on dorsal adductor field and foramen.

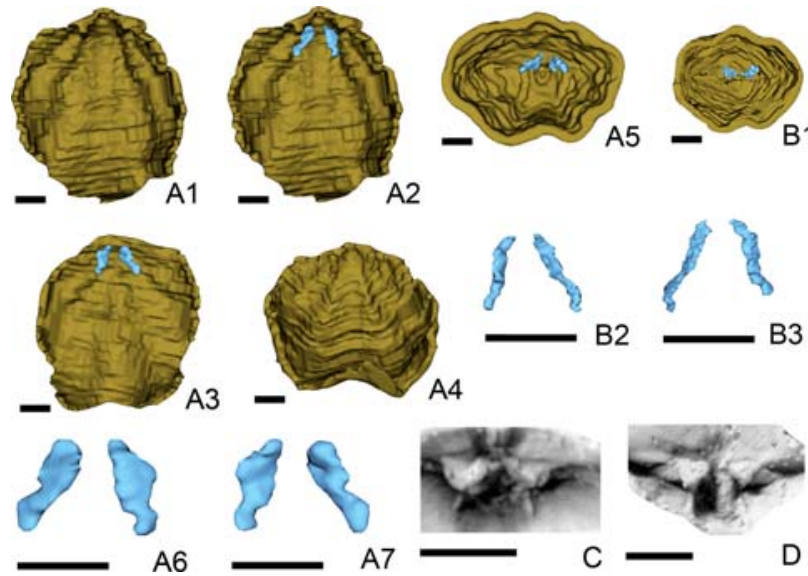

Figure 4. Three-dimensional reconstruction after serial sections $(\mathbf{A}, \mathbf{B})$ and latex casts of internal moulds $(\mathbf{C}, \mathbf{D})$ of articulated shells of Nannirhynchia pygmaea (Morris, 1847); section Maria Pares (Central Portugal); S. Gião Formation (Polymorphum Zone, early Toarcian); leg. M. Schemm-Gregory 2011. All figures magnified (A1-A5, B1: 3×; A6, A7, B2, B3: 9×); scale bars represent $1 \mathrm{~mm}$. A. UC-MP-155-2. Interior of ventral shell without (1) and with (2) crura, interior of dorsal shell with crura (3), oblique posterior view of ventral internal shell (4), anterior view of apical region of articulated shell (5), and dorsal (6) and ventral (7) views of crura; B. UC-MP-104-4. Anterior view of apical region of articulated shell (1), and ventral (2) and dorsal (3) views of crura. Juvenile specimen, note free portions of crura are longer and thinner than in adults (A6, A7); C. UC-MP-155-6. Anterior view of cardinalia, note difference in thickness of crura and dental plates; D. UC-MP-155-4. Anterior view of cardinalia, note embedding of ventral muscle scars into shell material.

nal shell morphology, especially the cardinalia and crura, however, less details of the muscle scars are seen in comparison to the pyritized internal moulds.

\section{Conclusions}

The three-dimensional reconstructions show the potential in studying internal shell morphology and enable a direct comparison between moulds and articulated
Table 1. Measurements of selected articulated shells of Nannirhynchia pygmaea (Morris, 1847) from section Maria Pares. Figured specimens are marked by the asterisk, sectioned specimens by the cross.

\begin{tabular}{llll}
\hline inv. nr. & $L(\mathrm{~mm})$ & $W(\mathrm{~mm})$ & $\mathrm{T}(\mathrm{mm})$ \\
\hline UC-MP-64-5* $^{*}$ & 4.9 & 5.0 & 3.6 \\
UC-MP-67-1* $^{*}$ & 5.6 & 6.3 & 3.4 \\
UC-MP-67-3* $^{*}$ & 6.1 & 6.0 & 4.3 \\
UC-MP-86-3* $^{*}$ & 5.3 & 5.7 & 3.8 \\
UC-MP-104-4 $^{+}$ & 3.9 & 4.3 & 3.5 \\
UC-MP-104-5+ & 5.2 & 5.5 & 4.1 \\
UC-MP-104-6+ & 5.9 & 5.8 & 4.5 \\
UC-MP-155-1+ & 6.0 & 5.9 & 4.7 \\
UC-MP-155-2+ & 5.3 & 5.9 & 4.1 \\
UC-MP-156-3* & 5.9 & 6.2 & 3.9 \\
\hline
\end{tabular}

Table 2. Measurements of selected internal moulds of articulated shells of Nannirhynchia pygmaea (Morris, 1847) from section Maria Pares. Figured specimens are marked by an asterisk, specimens figured as latex cast by the cross. Specimen UC-MP-156-19 is preserved as dorsal internal mould.

\begin{tabular}{llll}
\hline inv. nr. & $L(\mathrm{~mm})$ & $W(\mathrm{~mm})$ & $T(\mathrm{~mm})$ \\
\hline UC-MP-64-3* $^{*}$ & 5.1 & 5.5 & 5.5 \\
UC-MP-65-2* $^{*}$ & 6.8 & 6.7 & 4.6 \\
UC-MP-66-1* $^{*}$ & 5.7 & 6.2 & 4.4 \\
UC-MP-84-1* $^{*}$ & 5.2 & 6.0 & 3.8 \\
UC-MP-155-4 $^{+}$ & 5.4 & 6.1 & 4.3 \\
UC-MP-155-6 $^{+}$ & 4.5 & 5.4 & 2.8 \\
UC-MP-156-2* & 5.9 & 6.0 & 3.7 \\
UC-MP-156-8* & 6.7 & 6.4 & 4.2 \\
UC-MP-156-9* & 4.9 & 4.9 & 3.4 \\
UC-MP-156-12* & 4.9 & 5.5 & 3.6 \\
UC-MP-156-14* & 5.2 & 5.1 & 3.6 \\
UC-MP-156-15* & 5.3 & 5.7 & 3.6 \\
UC-MP-156-16* & 5.1 & 5.8 & 3.4 \\
UC-MP-156-17* & 5.6 & 5.4 & 3.6 \\
\hline
\end{tabular}



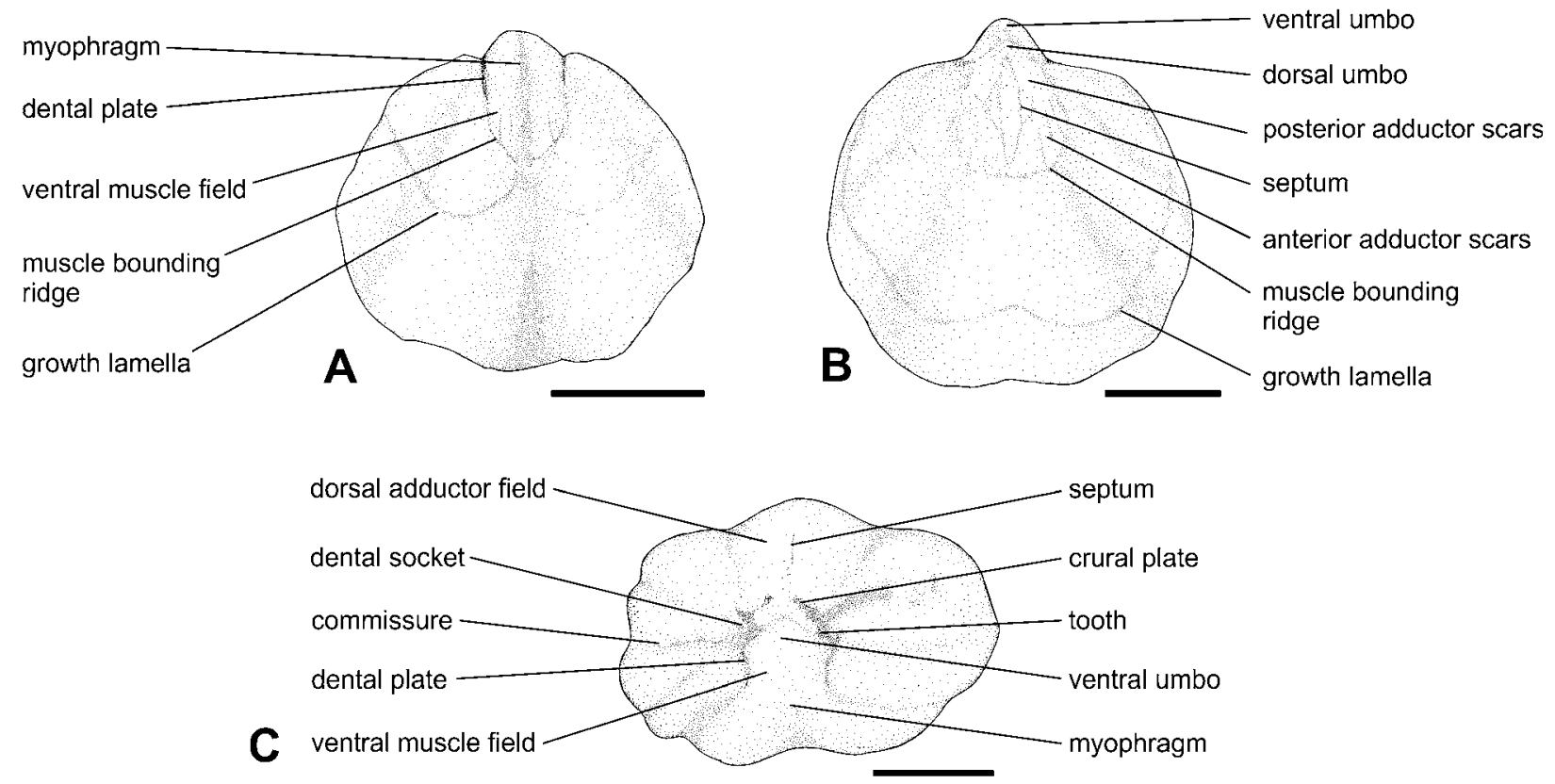

Figure 5. Morphological characters of Nannirhynchia pygmaea (Morris, 1847) preserved as pyritized internal moulds of articulated shells. Note that morphological features are preserved as negative forms. Scale bars represent 2 mm. A. UC-MP-156-9, ventral view; B. UC-MP-156-8, dorsal view; C. UC-MP-66-1, posterior view.

shells. The new data of the internal shell morphology of Nannirhynchia pygmaea (Morris, 1847) complements the former descriptions of this important brachiopod genus, which is particularly abundant in some Western European and North African outcrops, only based on external features. The complete characterization of the internal and external features of N. pygmaea allows a more detailed description of the internal morphology of this important index fossil of the Leptaena beds, represented by marly limestones with Leptaena fauna within the S. Gião Formation in the Lusitanian Basin. Furthermore, a correlation of this stratum in the Portuguese Lusitanian Basin with strata in the Normandy, northeastern Morocco, and western Algeria is possible where $N$. pygmaea occurs in an external platform facies.

\section{Acknowledgements}

The authors thank Michael Ricker (Frankfurt am Main) for providing us with literature and for helpful suggestions to solve technical problems. Page charges were paid by the Consortium Petrobras-Galp-Partex. M. S.-G. is grateful to Artur Sá (Vila Real) for providing lab facilities to prepare serial sections and latex casts. The final version of the manuscript has greatly benefited from the thorough reviews of Howard R. Feldman (New York) and Paul Sartenaer (Brussels).

\section{References}

Ager, D. V. 1959. A monograph of the British Liassic Rhynchonellidae. Part II. - Palaeontographical Society of London, Monograph 112 (483): $51-84$.

Ager, D. V. 1967. A monograph of the British Liassic Rhynchonellidae. Part VI. - Palaeontographical Society of London, Monograph 121 (519): 137-172.
Alméras, Y., Boullier, A. \& Laurin, B. 1997. Brachiopodes. In Cariou, E. \& Hantzpergue, P. (eds). Biostratigraphie du Jurassique ouesteuropéen et méditerranéen. zonations parellèlles et distribution des invertébrés et microfossiles. - Bulletin du Centre de recherches Elf Exploration Production, Mémoire 17: 169-195.

Alméras, Y., Mouterde, R., Elmi, S. \& Rocha, R. 1995. Le genre Nannirhynchia (Brachiopoda, Rhynchonellacea, Norellidae) dans le Toarcian Portugais. - Palaeontographica, Abteilung A 237: 1-38.

Barbosa, B., Soares, A. F., Rocha, R. B., Manupella, G. \& Henriques, M. H. 1998. Notícia explicativa da folha 19-A (Cantanhede) da Carta Geológica de Portugal, na escala 1/50000. Serviços Geológicos, Lisboa.

Buckman, S. S. 1918. The Brachiopoda of the Namyau Beds, Northern Shan States, Burma. - Memoirs of the Geological Survey of India, Palaeontologica Indica (new series) 3 (2): 1-229.

Cohen, A. S., Coe, A. L., Harding, S. M. \& Schwark, L. 2004. Osmium isotope evidence for the regulation of atmospheric $\mathrm{CO}_{2}$ by continental weathering. - Geology 32: 157-160.

Dagys, S. S. 1974. Triassic brachiopods (Morphology, classification, phylogeny, stratigraphical significance and biogeography). - Sibirskoe Otdelenie Izdatel'stvo "Nauka" 214: 1-387. [in Russian]

Dalman, J. W. 1828. Uppställning och Beskrifning af de I Sverige funne Terebratuliter. - Kongliga Svenska Vetenskapsakademien Handlingar for 1827 3: 85-155.

Davidson, T. \& Morris, J. 1847. Descriptions of some species of Brachiopoda. - The Annals and Magazine of Natural History 20: 250-257.

Deslongchamps, E. 1853. Mémoire sur les genres Leptaena et Thecidea des terrains jurassiques du Calvados. - Société Linnéene de Normandie, Mémoires 9: 13-250.

Duarte, L. V. 1990. Estudo sedimentológico das unidades calco-margosas toarcianas na região Rabaçal-Condeixa. Centro de Geociências da Universidade de Coimbra, Coimbra.

Duarte, L. V. 1995. O Toarciano da Bacia Lusitaniana. Estratigrafia e Evolução Sedimentogenética. Ph.D. Thesis, Universidade de Coimbra, Coimbra.

Duarte, L. V. 1997. Facies analysis and sequential evolution of the Toarcian-Lower Aalenian series in the Lusitanian Basin (Portu- 
gal). - Comunicações do Instituto Geológico e Mineiro de Lisboa 83: $65-94$.

Duarte, L. V. 2007. Lithostratigraphy, sequence stratigraphy and depositional setting of the Pliensbachian and Toarcian series in the Lusitanian Basin, Portugal. - Ciências da Terra (UNL) 16: 1723.

Duarte, L. V. \& Soares, A. F. 2002. Litoestratigrafia das séries margocalcárias do Jurássico Inferior da Bacia Lusitânica (Portugal). Comunicações do Instituto Geológico e Mineiro de Lisboa 89: $115-134$.

Duarte, L. V., Wright, V. P., Fernández-López, S. E., Krautter, M., Azerêdo, A., Henriques, M. H., Rodrigues, R. \& Perilli, N. 2004. Early Jurassic carbonate evolution in the Lusitanain Basin (Portugal): facies, sequence stratigraphy and cyclicity. In Duarte, L. V. \& Henriques, M. H. (eds). Carboniferous and Jurassic Carbonate Platforms of Iberia - 23rd IAS Meeting of Sedimentology, Coimbra, 2004, Field Trip Guidebook Volume 1, Coimbra: pp. 47-71.

Gahr, M. E. 2002. Palökologie des Makrobenthos aus dem UnterToarc SW-Europas. - Beringeria 31: 3-204.

Hallam, A. 1986. The Pliensbachian and Tithonian extinction events. - Nature 319: 765-768.

Hesselbo, S. P., Jenkyns, H. C., Duarte, L. V. \& Oliveira, L. C. V. 2007. Carbon-isotope record of the Early Jurassic (Toarcian) Oceanic Anoxic Event from fossil wood and marine carbonate (Lusitanian Basin, Portugal). - Earth and Planetary Science Letters 253: 455-470.

Jourdan, F., Féraud, G., Bertrand, H., Kampunzu, A. B., Tshosho, G., Watkeys, M. K. \& LeGall, B. 2005. Karoo large igneous province: Brevity, origin and relation to mass extinction questioned by new Ar/Ar age data. - Geology 33: 745-748.

Kuhn, O. 1949. Lehrbuch der Paläozoologie. E. Schweizerbart'sche Verlagsbuchhhandlung, Stuttgart.

Little, C. T. S. \& Benton, M. J. 1995. Early Jurassic mass extinction: a global long-term event. - Geology 23: 495-498.

Manceñido, M. O., Owen, E. F., Dagys, A. S. \& Sun Dongli. 2002. Norelloidea. In Kaesler, R. L. (ed). Treatise on Invertebrate Paleontology, Brachiopoda, Part H, vol. 4. revised - The Geological Society of America and The University of Kansas, Boulder, Colorado and Lawrence, Kansas: pp. 1308-1325.
Mattioli, E., Pittet, B., Bucefalo-Palliani, R. B., Rohl, H. J., SchmidRöhl, A. \& Morettini, E. 2004. Phytoplankton evidence for the timing and correlation of palaeoceanographical changes during the early Toarcian oceanic anoxic event (Early Jurassic). - Journal of the Geological Society London 161: 685-693.

Mouterde, R., Ruget, C. \& Moitinho de Almeida, F. 1965. Coupe du Lias au Sud de Condeixa. - Comunicações dos Serviços Geológicos de Portugal 48: 5-35.

Quenstedt, F. A. 1868-1871. Petrefactenkunde Deutschlands. Die Brachiopoden, Teil 1, vol. 2. Fues's Verlag (R. Reisland), Leipzig.

Rouselle, L. 1977. Spiriférines du Lias moyen et supérieur au Maroc (Rides Prérifaines; Moyen Atlas) et en Espagne (Chaîne Celtibérique orientale). - Notes du Service Géologique du Maroc 38 (268): 153-175.

Savage, N. M., Maceñido, M. O., Ellis, F. O., Carlson, S. J., Grant, R. E., Dagys, A. S. \& Sun Dongli 2002. Rhynchonellida. In Kaesler, R. L. (ed). Treatise on Invertebrate Paleontology, Brachiopoda, Part H, vol. 4. revised - The Geological Society of America and The University of Kansas, Boulder, Colorado and Lawrence, Kansas: pp. 1027-1040.

Soares, A. F., Marques, J. F. \& Sequeira, A. F. 2007. Notícia explicativa da Folha 19-D Coimbra-Lousã da Carta Geológica de Portugal, na escala 1/50000. Instituto Nacional de Engenharia, Tecnologia e Inovação, Lisboa.

Sutton, M. D, Briggs, D. E. G., Siveter, David J. \& Siveter, Derek J. 2001. Methodologies for the visualization and reconstruction of three-dimensional fossils from the Silurian Herefordshire Lagerstätte. - Paleontologia Electronica 4 (1), art. 2, 17 pp., 1MB. [http://palaeo-electronica.org/2001_1/s2/issue1_01.htm].

Sutton, M. D, Briggs, D. E. G., Siveter, David J. \& Siveter, Derek J. 2005. Silurian brachiopods with soft-tissue preservation. - Nature 436: 1013-1015.

Vörös, A. 2002. Victims of the Early Toarcian anoxic event: the radiation and extinction of Jurassic Koninckinidae (Brachiopoda). Lethaia 35: 345-357.

Wignall, P. B., Newton, R. J. \& Little, C. T. S. 2005. The timing of paleoenvironmental change and cause-and-effect relationships during the Early Jurassic mass extinction in Europe. - American Journal of Science 305: 1014-1032. 